Article

\title{
Sustainable Palm Oil Certification Scheme Frameworks and Impacts: A Systematic Literature Review
}

\author{
Norhana Abdul Majid, Zaimah Ramli *D, Sarmila Md Sum (D) and Abd Hair Awang (D) \\ Development Studies, Faculty of Social Science and Humanities, Universiti Kebangsaan Malaysia (UKM), \\ Bangi 43600, Selangor, Malaysia; nabdulma74@gmail.com (N.A.M.); sarmila.mdsum@ukm.edu.my (S.M.S.); \\ hair@ukm.edu.my (A.H.A.) \\ * Correspondence: zaimahr@ukm.edu.my
}

Citation: Abdul Majid, N.; Ramli, Z.; Md Sum, S.; Awang, A.H. Sustainable Palm Oil Certification Scheme Frameworks and Impacts: A Systematic Literature Review. Sustainability 2021, 13, 3263. https://doi.org/10.3390/su13063263

Academic Editor: Sara González García

Received: 1 February 2021

Accepted: 9 March 2021

Published: 16 March 2021

Publisher's Note: MDPI stays neutral with regard to jurisdictional claims in published maps and institutional affiliations.

Copyright: (c) 2021 by the authors. Licensee MDPI, Basel, Switzerland. This article is an open access article distributed under the terms and conditions of the Creative Commons Attribution (CC BY) license (https:// creativecommons.org/licenses/by/ $4.0 /)$.

\begin{abstract}
Sustainability certification schemes were introduced to the palm oil industry as a response to address the negative environmental and social impacts associated with the development of this industry. The first certification scheme for palm oil, the Roundtable of Sustainable Palm Oil (RSPO), was established in 2004, followed by other non-governmental initiatives to ensure the sustainable production of palm oil. Indonesia and Malaysia, the two largest palm oil producers in the world, established Indonesia Sustainable Palm Oil (ISPO) and Malaysia Sustainable Palm Oil (MSPO) in 2011 and 2015, respectively. This article aims to analyze the existing literature related to studies on the RSPO, MSPO and ISPO on the basis of articles identified from the SCOPUS (scopus.com) and Web of Science (clavirate.com) databases. Results showed that research on the RSPO has been widely conducted compared with that on MSPO and ISPO. Thus, further research on MSPO and ISPO is needed to understand the dynamics of the implementation of sustainability certification. This article also provides an insight on how sustainable certification in the palm oil industry, particularly MSPO, could contribute to achieving the Sustainable Development Goals (SDGs).
\end{abstract}

Keywords: agriculture sustainability; palm oil; Malaysia sustainable palm oil; round-table of sustainable palm oil; sustainability certification

\section{Introduction}

The global demand for palm oil continues to increase in tandem with growth of the world population. The versatility of palm oil as an ingredient in products ranging from processed foods to cosmetics and biofuel, coupled with a market price below that of its competitors, makes it one of the most sought-after vegetable oils. Malaysia and Indonesia are the two largest palm oil producers in the world, accounting for more than $85 \%$ of global production, followed by Thailand and Colombia [1]. The development of the palm oil industry continues to face various criticisms, with accusations of deforestation, peat destruction, loss of biodiversity and exploitation [2]. Consumption of palm oil has been linked to health issues (such as cancer risk, mortality rate and toxic contaminants), particularly cardiovascular diseases due to the saturated content in palm oil [3,4]. However, various studies have indicated that there is no conclusive evidence linking palm oil and cardiovascular disease, and its benefits have been discussed across the literature [5-7]. The usage of palm oil has traditionally been in both the food sector $(80 \%)$ and non-food sector $(20 \%)$ including biodiesel and oleochemicals [8]. With the growing demand for alternative fuels, palm oil biodiesel has been identified as a renewable resource and has fueled the increase of palm oil exports to Europe [9,10]. The Expert Market Research (EMR) [11] has forecast growth in the global palm oil market for 2021 and 2026 at an average of 5\%, rising from 82.8 million tons to 111 million tons. Palm oil accounts for $31 \%$ of biodiesel raw material in the Southeast Asian market. The European Union (EU) consumed 87\% of palm oil imports for the year 2017 to produce biodiesel. With robust EU legislation around palm oil for biodiesel production, market demand is expected to increase. Growing population 
and changing consumer preferences are also driving palm oil related products such as bio-detergents, skincare products, lipsticks and soaps [11]. This has sparked concern about sustainability in the European market, which has continuously maintained their stand for certified and sustainable palm oil as part of its importation requirements [12]. This stand was further strengthened by the pledge under the Amsterdam Declaration in 2015, whereby six countries in the European Union have committed to $100 \%$ sustainable sourcing and trade and the increased traceability of this commodity by no later than 2020 [13]. As the world's population is expected to increase to 9 billion by 2050, an additional 35 million tonnes of oils and fats will be needed every year [14]. Therefore, the demand for palm oil is expected to increase, which also means pressure for producing countries to ensure the sustainable production and development of the palm oil industry.

The establishment of the Roundtable on Sustainable Palm Oil (RSPO) in 2004 was a turning point for the palm oil industry in the fight against the negative allegations and showed its commitment toward sustainable development. The RSPO was founded with the objective of promoting the growth and usage of sustainable palm oil products through credible international standards [15]. As the demand for certified sustainable palm oil (CSPO) grew, producing countries have taken the initiative to establish their own sustainability standards. The Indonesian government established Indonesia Sustainable Palm Oil (ISPO) in 2011 to ensure that all Indonesian palm oil growers, not just those exporting to foreign markets, conform to higher agricultural standards [16]. In 2015, Malaysian Sustainable Palm Oil (MSPO) was introduced as a national standard by the Malaysian government to shows its commitment toward sustainable palm oil production. Well-planned and monitored cultivation and processing of palm oil can mitigate carbon stock degradation and enhance conservation values [17-19]. By specifically introducing the MSPO, the Malaysia Palm Oil Board (MPOB) is strongly committed to the maintenance of, and mitigating the impact on, environmental ecosystems for the safe and healthy production of palm oil-based products. Therefore, compliance with MSPO became mandatory for all Malaysian palm producers on 31 December 2019 [20].

\section{Sustainability Certification Framework}

The importance of sustainable development continues to take center stage with 193 countries adopting the 2030 Agenda for Sustainable Development and its 17 Sustainable Development Goals (SDGs) in 2015 [21]. The SDGs, officially known as Transforming our World: the 2030 Agenda for Sustainable Development, set out an ambitious plan of action for people, the planet, prosperity, peace and partnership, with the objective of leaving no one behind [22]. The present paper is aimed at identifying and reviewing the research on palm oil sustainability certification in relation to its environmental, social and economic sustainability.

Certification is a procedure by which a third party provides written assurance that a product, process or service along the supply chain conforms with certain standards [23]. In the context of palm oil production plantations or milling, refinery companies having been certified means that their products are sustainably produced and they have undertaken the necessary actions to minimize any negative environmental and social impacts. However, this certification is whitewashing the real issue of sustainability, particularly the environmental and social issues [24]. Various voluntary and mandatory standards with different levels of objectives, scope, criteria and methodologies currently apply to the palm oil industry. According to SPOTT [16] and McInnes [25], several certification standards support responsible and certified palm oil production. The sustainability certifications in the palm oil industry include the RSPO, MSPO, ISPO, International Sustainability and Carbon Certification (ISCC) and the Roundtable on Sustainable Biomaterials and Sustainable Agriculture Networks (RSBSAN) [16,25]. MSPO and ISPO are mandatory government-led certification schemes, whilst the RSPO and ISCC are implemented on a voluntary basis.

Since its establishment in 2004, the RSPO continued to develop and strengthen to cater for the needs of the industry and the requirements of consumers. The introduction of RSPO 
in 2016 aimed to further improve the transparency and credibility of the RSPO [26]. The RSPO is currently the largest voluntary certification scheme for sustainable palm oil [27]. In addition, 19\% or 15.67 million tonnes of palm oil produced has been RSPO certified [28]. ISPO and MSPO are Indonesian and Malaysian government initiatives that are based on each country's national laws and regulations and were adopted on the basis of the national interpretation of the RSPO [26]. ISPO is a mandatory scheme since its establishment in 2011 [26,29], whilst MPSO became mandatory on 31 December 2019 [8]. As of 31 December $2019,3.6$ million hectares or $62.26 \%$ of the total palm oil planting areas have been certified by MSPO [28]. The RSPO is a voluntary scheme whereby producers are not forced to comply with the scheme. However, the mandatory requirements of ISPO and MSPO ensures producers adopt some type of standard as a minimum requirement for sustainable production, which is beneficial to them [26].

In the context of the ASEAN region of palm oil production, the three most widely used certification schemes by Malaysia and Indonesia are the RSPO, MSPO and ISPO. The stakeholders within the supply chain must comply with the standards set by the certification to be certified. Generic standards for defining sustainable palm oil production were introduced and these standards are applied and audited when certifying palm oil producers [30]. These standards contain principles, criteria and indicators generally aimed at sustainable production with the intention of mitigating the negative social and environmental impacts. They also imply the introduction of a traceability system, good agricultural practices, improved natural resource management and environmental responsibility and compliance with the existing regulations [31,32]. The principles of the RSPO, MSPO and ISPO are enumerated in Table 1.

Table 1. Principles of the RSPO, MSPO and ISPO.

\begin{tabular}{|c|c|c|c|}
\hline Principles & 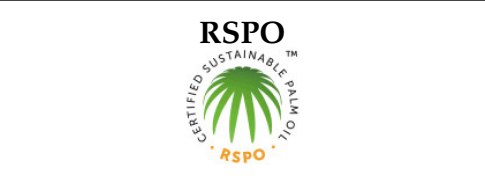 & MSPO & $+\infty^{\text {ISPO }}$ \\
\hline Principle 1 & $\begin{array}{l}\text { Behave ethically and } \\
\text { transparently }\end{array}$ & $\begin{array}{l}\text { Management commitment and } \\
\text { responsibility }\end{array}$ & $\begin{array}{l}\text { Legality of Plantation } \\
\text { Businesses }\end{array}$ \\
\hline Principle 2 & Operate legally and respect rights & Transparency & Plantation Management \\
\hline Principle 3 & $\begin{array}{l}\text { Optimize productivity, efficiency, } \\
\text { positive impacts and resilience }\end{array}$ & Compliance with legal requirements & $\begin{array}{l}\text { Protection of the utilization of } \\
\text { Primary Forest and Peatlands }\end{array}$ \\
\hline Principle 4 & $\begin{array}{l}\text { Respect Community and human } \\
\text { rights and deliver benefits }\end{array}$ & $\begin{array}{l}\text { Social responsibility, safety and } \\
\text { employment conditions }\end{array}$ & Environmental Management \\
\hline Principle 5 & Support smallholder inclusion & $\begin{array}{l}\text { Environment, natural resources, } \\
\text { biodiversity and ecosystems services }\end{array}$ & Responsibility for Workers \\
\hline Principle 6 & $\begin{array}{l}\text { Respect workers' rights and } \\
\text { conditions }\end{array}$ & Best practice & $\begin{array}{l}\text { Responsibility for Social and } \\
\text { Economic Empowerment }\end{array}$ \\
\hline Principle 7 & $\begin{array}{l}\text { Protect, conserve and enhance } \\
\text { ecosystems and the the } \\
\text { environment }\end{array}$ & Development of new plantings & $\begin{array}{l}\text { Continuous Business } \\
\text { Improvement }\end{array}$ \\
\hline
\end{tabular}

Sources: https: / rspo.org/about (accessed on 16 November 2019); doi:10.21894/jopr.2019.0038; doi:10.1007/s10460-017-9816-6.

\section{Materials and Methods}

The method used in this research is the systematic literature review (SLR). This method adheres closely to a set of scientific methods that explicitly aim to limit systematic error (bias), mainly by attempting to identify, appraise and synthesize all relevant studies (of whatever design) to answer a particular question or set of questions [33]. According to Xiao and Watson [34], all the reviews can be conducted through the following eight common steps: (1) formulating the research problem, (2) developing and validating the 
review protocol, (3) searching the literature, (4) screening for inclusion, (5) assessing quality, (6) extracting data, (7) analyzing and synthesizing data, (8) reporting the findings.

The literature search was performed in two databases, Scopus (scopus.com) and Web of Science (clavirate.com). These are the two most widespread databases on different scientific fields and are frequently used for searching the literature [35]. They allow searching and sorting of the search results by expected parameters, such as first author, citation, institutions, impact factor and h-index [36]. In addition, both databases have the feature of calculating the impact factor and h-index of journals within their databases. The Impact factor and h-index have become the standard proxies to measure quality and academic performance, with a higher impact factor and h-index signifying the importance of the journal and the researcher's contribution [37].

The databases were searched using the terms 'palm oil', 'oil palm', 'certification*' and sustainability. Sources were then selected based on papers from journals published from 2004 until 15 November 2019. The selected articles were independently analyzed according to titles and abstracts with a focus on the three main certification schemes of the RSPO, MSPO and ISPO. The databases retrieved 174 articles and these were further screened by removing duplicates, thus reducing the number of articles to 115 . After the titles and abstracts were screened, the articles were further reduced to 72 and content screening resulted in 50 articles being identified in this review. The results were then categorized into issues or research related to the certification schemes from a triple bottom line standpoint. The database search and screening selection are illustrated in Figure 1.

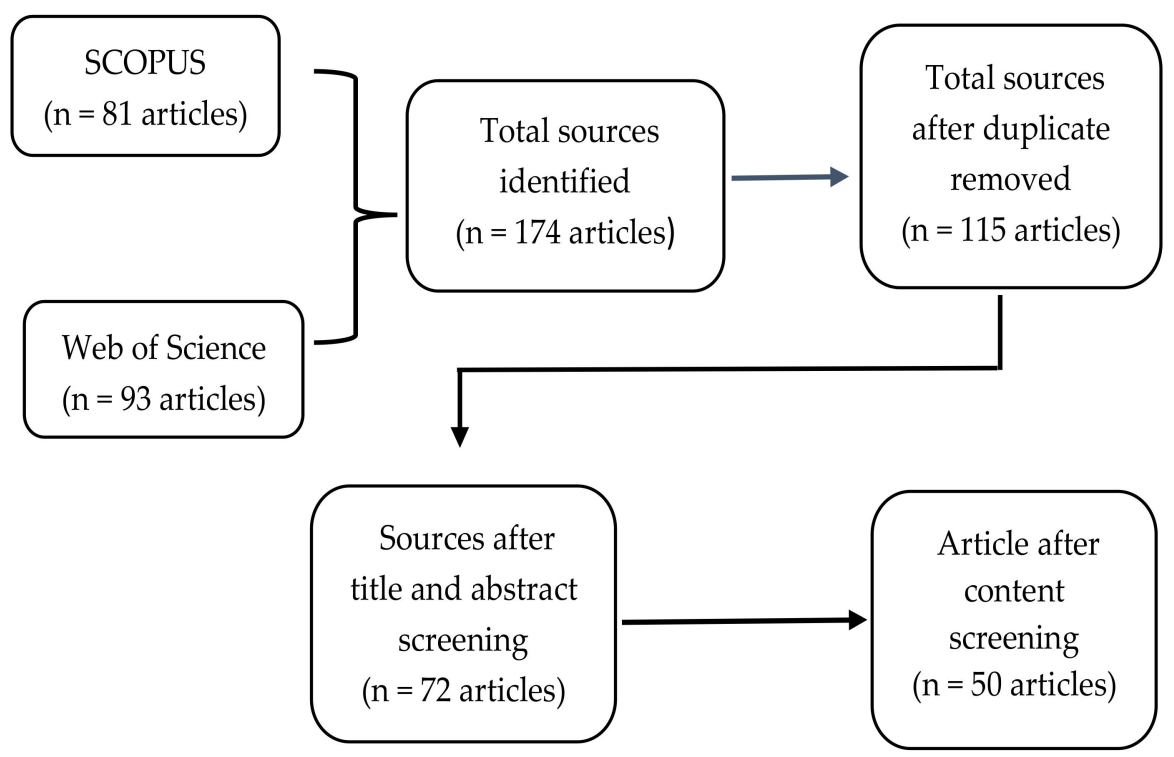

Figure 1. The Flow of the database search and screening selection.

\section{Results}

The RSPO was the most researched certification scheme, with 32 papers. One paper focused on MSPO and four were about ISPO. Thirteen papers focused on two or more certification schemes. A total of 19 studies focused on the implementation of sustainable certification in Indonesia, four studies focused on Malaysian adoption of sustainable certification and two studies concentrated on Thailand, Colombia and Ecuador. A total of 21 studies were centered around two or more countries that cultivate palm oil. Sustainability certifications have environmental, social and economic implications on sustainable development, and these implications have been the focus of previous research.

\subsection{Environmental and Biodiversity Preservation Component}

Studies on environmental impact and sustainable certification currently seems to be lacking and with mixed results. The stringent requirements of the RSPO principles 
and criteria for native vegetation could complement the existing policies in producer countries to address the overall sustainability concerns about the development of the palm oil industry [38]. The study by Carlson et al. [39] indicates that certification reduced deforestation by $33 \%$ from a counterfactual of 9.8 to $6.6 \% \mathrm{y}^{-1}$. However, sustainable certification does not prevent forest loss from occurring, as $40 \%$ of the RSPO concession area suffered from forest loss due to deforestation, fire or tree damage during a period of 15 years in Malaysia, Indonesia and Papua New Guinea [40]. Despite plantations being certified, there was no evidence to support sustainability in biodiversity conservation and the reduction of fires $[39,41]$. A study in Jambi, Indonesia showed that the requirement of good agricultural practices in the RSPO certification does not necessarily influence smallholders to uphold management practices for increased sustainability [42]. However, based on research in Colombia, evidence of enhanced environmental practices was found amongst certified producers at the farm level, including the substitution of synthetic fertilizers with organic. Only $2 \%$ of the certified farmers used herbicide compared to $28 \%$ of non-certified farmers. Larger areas of the farms were set aside for conservation with $7 \%$ of the certified farms allowing hunting and fishing activities on their farms and $26 \%$ of non-certified farms allowing the same activities [43]. A study by Saswattecha et al. [44] concluded that RSPO-certified producers at the Tapi Basin in Thailand caused the lowest environmental impact compared with non-certified producers. Implementing best practices and adherence to the certification principles and criteria in the mills would reduce the environmental impact during CPO production. The study concluded that the non RSPO certified mills contributed to $58-75 \%$ of the environmental impact, while the RSPO certified mills $(\leq 10 \%)$ and potentially certified mills contributed $23-34 \%$. Whilst certifying the sustainable production of palm oil, certification standards may bring unintended consequences, as seen in Indonesia and Ghana when both countries adopted the RSPO [30]. Given that palm oil generates a much more lucrative income, a shift in the planting of agriculture crops either by smallholders or through government policies, whereby smallholders in Indonesia change their paddy fields to palm oil, has been observed. The need to adhere to the strict RSPO standards of no deforestation has unintentionally changed the landscape in Indonesia, where the land available for rice and other food crops has been reduced.

\subsection{Socio-Economic Component}

From a social perspective, the adoption and impact of certification on smallholders from various aspects including livelihood, management, compliance with certification and agricultural practices, has been widely explored [32,41,42,45-47]. The impact of the RSPO on smallholders has been studied by Hutabarat et al., [32], Brandi et al. [45], Hidayat et al. [48] and Hidayat et al. [49]. Their studies focused on the RSPO because this scheme is in the forefront of palm oil certification since its formation in 2004 . The requirement for group certification in the RSPO has changed the organizational structure for smallholders and provides them with better access for training, credit facilities and participation in farmer organizations $[48,49]$. Independent smallholders are the focus of the studies because they are facing challenges in adopting the certification. The results showed that smallholders generally lack the knowledge, skill, financial capabilities and resources to implement the certification on their own $[45,47,50]$.

Most literature acknowledged the need to involve smallholders in the production of sustainable palm oil. However, solutions to mitigate this issue are lacking. When looking at the current RSPO certification process for smallholders, severe limitations need to be addressed in terms of capacity constraints and resource requirements. Consequently, a bigdata analytical framework for sustainable palm oil production was proposed to address those limitations [51]. The implementation of MSPO through the setup of Sustainable Palm Oil Clusters and the training by TUNAS officers (extension officers) demonstrated a positive impact on smallholder transformation towards becoming a more sustainable community [52]. Organizational structure also plays an important role as a conduit to 
facilitate the adoption of certification. The authors of [53] confirmed the direct and indirect effects of farmer organizations on the achievement of sustainability. ISPO certification did not have a direct impact on sustainability, but farmer organizations are one aspect of the ISPO that had a direct impact on sustainability. Oosterveer et al., [30] identified the unintended social consequences of the implementation of the RSPO based on a case study in Indonesia and Ghana. Certain groups, such as smallholders with fields in high conservation value $(\mathrm{HCV})$ areas, independent smallholders and women, were excluded during the adoption of the RSPO certification.

A study by Hutabarat et al. [32] found that the cost of palm oil plantation management for smallholdings increased due to increased management costs and fees. Different types of smallholders face different challenges in adopting certification and the impact of certification on yield and income varies $[32,45,48,54]$. For certification to be economically feasible, there should be an increase of at least $14.3 \%$ in fresh fruits bunches yield and $9.4 \%$ in the price for certification to be viable, as demonstrated in the field study on the Amanah Independent Oil Palm Smallholders Association in the Ukui District, Indonesia [32]. However, other factors such as production costs and availability of a price premium would determine if certified palm oil can deliver economic returns in the long run. Two studies focused on the relationship between sustainability certification on financial profitability and export operational profitability. Both studies showed no significant difference in the operating profitability due to sustainability certification between the palm oil exporting and non-exporting companies [55]. In addition, the profitability of firms with sustainability certification was almost $2 \%$ higher than that of firms without certification [56].

\subsection{Legal and Procedural Components}

Studies on the governance of the RSPO and the adoption of sustainability standards by producers' governments have been reported [57-67]. Martens et al., [68] pointed out that the RSPO failed to completely meet the legal and procedural aspects of good governance practices, as the smallholders neither perceived themselves as part of the vertical palm-oil supply chain nor linked the RSPO to any stakeholders whom they may consider to be important. This affected smallholder inclination toward adopting the RSPO. These findings highlighted the importance of governance processes in transforming the palm oil business to a sustainable one. In developing the principles and criteria of the certification scheme, smallholders are among the stakeholders being mostly neglected, whose involvement is needed to fulfil a certain portion of the requirements for certification [47,69]. Mohd Noor et al. [69] proposed a livelihood setting approach, where the company invests in the social and human capital of the smallholders through policies and the rewarding of good practices. Thorough investment in community capital could bring a positive outcome and improve the smallholders' livelihood and managerial skills.

\section{Discussion}

Sustainability certification could be an effective tool in assisting the palm oil industry in achieving the SDGs. Moving forward, certification schemes could also play a bigger role in facilitating the palm oil industry to achieve SDGs by 2030. The requirement for producers, including plantations and smallholders, to fulfil a set of standards and to be assessed by a third party or auditors, could bring to them the benefits of a more effective execution of sustainability in order to achieve the SDGs. The principles generally cover a similar set of general themes which are legality, environmental responsibilities, social responsibilities and business practices [29]. These themes indirectly address the following five pillars of sustainable development under the SDGs: people, planet, prosperity, peace and partnership. Although the execution and impact of each differs, the main scheme principles coupled with the right mechanism, policy and partnership could strengthen the palm oil industry commitment toward achieving SDGs. The 17 goals and 169 associated targets of the SDGs aim to tackle social, environmental and economic challenges, from ending poverty and hunger to providing universal access to water and energy, action on 
climate change and stopping biodiversity loss [70]. With the focus on measurable economic, social and environmental improvements, sustainability standards could contribute to the achievement of many of the overarching goals and specific targets of the SDGs [71].

The palm oil industry in Malaysia has been instrumental in contributing toward economic growth and poverty alleviation. On average, the industry contributes between $5 \%$ and 7\% of the country's GDP, with export revenue averaging RM64.24 billion annually for the period of 2014-2018 [72]. This showed the importance of the industry to the economy and it could be translated into increased incomes and the livelihoods of 500,000 palm oil smallholders in Malaysia. The adoption of certification could assist smallholders in improving their agricultural practices, that could then translate into improved yield and a subsequent increase in income [73]. It could also contribute to achieving goals (1) to end poverty in all its forms everywhere and (2) to end hunger, achieve food security and improve nutrition and to promote sustainable agriculture. The principle 6 of MSPO on best practices could contribute to promoting sustainable agriculture (goal 2) amongst palm oil planters and smallholders. Studies in Indonesia indicated that smallholders who adopted the RSPO certification improved their livelihoods and increased their economic returns; they were also better trained in fertilizer, herbicide and pesticide application and handling than non-certified independent smallholders $[32,45,48]$.

MSPO certification requires legal compliance and safety and health requirements in place to indirectly support various SDGs, including goals 3, 6 and 8 . For example, principles 3 and 5 require palm oil planters to adhere to the legal requirements and take the necessary steps to protect the environment, natural resources, biodiversity and ecosystem services. MSPO certification, which advocates zero burning, could also contribute toward reducing incidences of haze from fires, thus complying with goal 3 for healthy lives and wellbeing, specifically goal 3.9.1 (the mortality rate attributed to household and ambient air pollution). Mohd Noor et al. [69] and Campbell [74] provided an insight on how the palm oil industry contributes to goal 6 (securing the availability and sustainable management of water and sanitation for all), whereby palm oil mills could be required to improve their wastewater treatment and mill effluent. Goal 12 (responsible consumption and production) is an important goal, directly linked to the need to improve agricultural and industrial practices for certified and sustainable palm oil production. As the population increases, the demand for palm oil in various applications continues to rise in tandem with the pressure for sustainable palm oil, which could be provided through sustainability certification. The benefit of MSPO on environmental protection could assist in achieving goals 13 (climate action) and 15 (life on land). Mandatory implementation of MSPO would require all stakeholders, including the private sector, governments and NGOs within the palm oil industry, to collaborate and form partnerships to achieve SDGs, as indicated in goal 17.

\section{Conclusions}

Sustainability schemes aim to ensure that the development of the palm oil industry does not contribute to further deforestation and environmental degradation but contributes to improving the social wellbeing of the workers and the communities involved. Producing countries, such as Malaysia and Indonesia, have taken a step further by developing their own sustainability schemes. Palm oil is an efficient oil that could fulfil the expected oil and fat requirements and demand with the increase in global population to 9.7 billion by 2050. This review highlights that a range of research has been undertaken in relation to environmental, social and economic sustainability. Some studies suggested a new or improved framework to ensure implementation of the RSPO or other certification schemes. However, studies focusing on MSPO are still lacking as this scheme was only established in 2015 compared with the RSPO and ISPO. Given the dynamics and differences in terms of governance and implementation, further research on MSPO and ISPO should be conducted to strengthen the producing countries' commitment toward environmental and social sustainability. Despite the varying results on certification effectiveness in delivering multiple sustainability objectives, certification has been the practical mechanism in managing and 
monitoring the sustainable production of certified sustainable palm oil thus far. Through the implementation of sustainable certification, the palm oil industry can play a significant role in achieving the SDGs. The limitation of this study is the number of databases used to search for articles, indicating that other related articles from other databases may not have been considered, which may result in a lack of critical analysis on other studies on the RSPO, MSPO and ISPO. An empirical study must be conducted to gain an enhanced understanding and knowledge on MSPO and its contribution to or impact on the SDGs.

Author Contributions: Methodology, S.M.S.; Supervision, Z.R. and A.H.A.; Writing-original draft, N.A.M.; Writing—review \& editing, Z.R. All authors have read and agreed to the published version of the manuscript.

Funding: This research and APC was funded by MPOB-UKM Endowment Chair (grant number MPOB-UKM-2020-008).

Institutional Review Board Statement: This study not involving humans or animals. We just review the previous studies. Therefore, the Institutional Review Board Statement is Not Applicable and can be exclude this statement.

Informed Consent Statement: This paper not involving human as a respondent of the study. This paper is about literature reviews. Therefore, informed consent statement is not applicable.

Data Availability Statement: Not applicable.

Conflicts of Interest: The authors declare no conflict of interest.

\section{References}

1. Ramadhani, T.N.; Santoso, R.P. Competitiveness analyses of Indonesian and Malaysian palm oil exports. Econ. J. Emerg. Mark. 2019, 11, 46-58. [CrossRef]

2. Ching, J.Y.L.; Yaman, I.C.; Khoon, K.L.; Hong, C.K.; Melayong, G. A case study into the sustainability journey and biodiversity conservation projects in Sarawak BY Sarawak oil palms berhad. J. Oil Palm Res. 2019, 31, 489-495. [CrossRef]

3. McNamara, D.J. Palm oil and health: A case of manipulated perception and misuse of science. J. Am. Coll. Nutr. 2010, 29, 240S-244S. [CrossRef]

4. Mukherjee, S.; Mitra, A. Health effects of palm oil. J. Hum. Ecol. 2009, 26, 197-203. [CrossRef]

5. Gesteiro, E.; Guijarro, L.; Sánchez-Muniz, F.J.; del Carmen Vidal-Carou, M.; Troncoso, A.; Venanci, L.; Jimeno, V.; Quilez, J.; Anadón, A.; González-Gross, M. Palm oil on the edge. Nutrients 2019, 11, 2008. [CrossRef]

6. Ismail, S.R.; Maarof, S.K.; Ali, S.S.; Ali, A. Systematic review of palm oil consumption and the risk of cardiovascular disease. PLoS ONE 2018, 13, e193533. [CrossRef] [PubMed]

7. Loganathan, R.; Subramaniam, K.M.; Radhakrishnan, A.K.; Choo, Y.-M.; Teng, K.-T. Health-promoting effects of red palm oil: Evidence from animal and human studies. Nutr. Rev. 2017, 75, 98-113. [CrossRef]

8. Basiron, Y.; Weng, C.K. The oil palm and its sustainability. J. Oil Palm Res. 2004, 16, 1-10.

9. Bentivoglio, D.; Bucci, G.; Finco, A. Revisiting the palm oil boom in Europe as a source of renewable energy: Evidence from time series analysis. Qual. Access Success 2018, 19, 59-66.

10. Mekhilef, S.; Siga, S.; Saidur, R. A review on palm oil biodiesel as a source of renewable fuel. Renew. Sustain. Energy Rev. 2011, 15, 1937-1949. [CrossRef]

11. EMR. Global Palm Oil Market Report and Forecast 2021-2026. EMR Food and Beverages Insight; EMR: Sheridan, WY, USA, 2021.

12. Pacheco, P.; Gnych, S.; Dermawan, A.; Komarudin, H.; Okarda, B. The Palm Oil Global Value Chain: Implications for Economic Growth and Social and Environmental Sustainability; CIFOR: Bogor, Indonesia, 2017. [CrossRef]

13. European Union. The Amsterdam Declaration in Support of a Fully Sustainable Palm Oil Supply Chain by 2020. Available online: http:/ / www.euandgvc.nl/documents / publications/2015/december/7/declarations-palm-oil (accessed on 3 December 2015).

14. Malaysian Palm Oil Council. Putting on the Brakes-Palm Oil Today. Available online: http://palmoiltoday.net/putting-on-thebrakes / (accessed on 21 November 2019).

15. Roundtable on Sustainable Palm Oil. RSPO Background. Available online: https://rspo.org/about (accessed on 16 November 2019).

16. SPOTT. Sustainability Policy Transparency Toolkit. Available online: https://www.sustainablepalmoil.org/wp-content/uploads/ sites/2/2015/09/Efeca_PO-Standards-Comparison.pdf (accessed on 16 November 2019).

17. Sumarga, E.; Hein, L.; Hooijer, A.; Vernimmen, R. Hydrological and economic effects of oil palm cultivation in Indonesian peatlands. Ecol. Soc. 2016, 21. [CrossRef]

18. Begum, H.; Alam, A.F.; Er, A.C.; Ghani, A.B.A. Environmental sustainability practices among palm oil millers. Clean Technol. Environ. Policy 2019, 21, 1979-1991. [CrossRef] 
19. Uning, R.; Latif, M.T.; Othman, M.; Juneng, L.; Hanif, N.M.; Nadzir, M.S.M.; Maulud, K.N.A.; Jaafar, W.S.W.M.; Said, N.F.S.; Ahamad, F.; et al. A review of Southeast Asian oil palm and Its $\mathrm{CO}_{2}$ fluxes. Sustainability 2020, 12, 5077. [CrossRef]

20. Sivanandam, H. MSPO Certification Mandatory by 2019. Available online: https://www.thestar.com.my/news /nation/2017/0 2/25/mspo-certification-mandatory-by-2019-govt-aims-for-sustainable-oil-palm-industry (accessed on 21 November 2019).

21. United Nations (UN). The Sustainable Development Agenda. 2016. Available online: https://www.un.org/sustainabledevelopment/ development-agenda/ (accessed on 25 January 2021).

22. United Nations. Transforming Our World: The 2030 Agenda for Sustainable Development. In A New Era in Global Health. Available online: https:/ / doi.org/10.1891/9780826190123.ap02 (accessed on 9 November 2018).

23. Dankers, C.; Liu, P.; Lawrence, T. Environmental and Social Standards, Certification and Labelling for Cash Crops. 2003. Available online: http:/ / www.fao.org/3/Y5136E/Y5136E00.pdf (accessed on 30 December 2019).

24. Pye, O. Commodifying sustainability: Development, nature and politics in the palm oil industry. World Dev. 2018. [CrossRef]

25. McInnes, A. A Comparison of Leading Palm Oil Certification Standards. 2017. Available online: https://www.forestpeoples.org/ en/responsible-finance-palm-oil-rspo/report/2017/comparison-leading-palm-oil-certification-standards (accessed on 2 October 2019).

26. Ivancic, H.; Koh, L.P. Evolution of sustainable palm oil policy in Southeast Asia. Cogent Environ. Sci. 2016, 2, 1-10. [CrossRef]

27. Dauvergne, P. The global politics of the business of "sustainable" palm oil. Glob. Environ. Politics 2018, 18, 34-52. [CrossRef]

28. Malaysian Palm Oil Certification Council. MSPO Trace 2019. Available online: https://mspotrace.org.my/ (accessed on 31 December 2019).

29. SPOTT. Standards for Palm Oil Production. Available online: https://www.spott.org/palm-oil-resource-archive/standards/ (accessed on 16 November 2019).

30. Oosterveer, P.; Adjei, B.E.; Vellema, S.; Slingerland, M. Global sustainability standards and food security: Exploring unintended effects of voluntary certification in palm oil. Glob. Food Secur. 2014, 3, 220-226. [CrossRef]

31. Brandi, C.; Cabani, T.; Hosang, C.; Schirmbeck, S.; Westermann, L.; Wiese, H. Sustainability Certification in the Indonesian Palm Oil Sector. 2013. Available online: https://www.die-gdi.de/uploads/media/Studies_74.pdf (accessed on 30 December 2019).

32. Hutabarat, S.; Slingerland, M.; Rietberg, P.; Dries, L. Costs and benefits of certification of independent oil palm smallholders in Indonesia. Int. Food Agribus. Manag. Rev. 2018, 21, 681-700. [CrossRef]

33. Petticrew, M.; Roberts, H. Systematic Reviews in the Social Sciences; Blackwell Publishing: Hoboken, NJ, USA, 2006. [CrossRef]

34. Xiao, Y.; Watson, M. Guidance on conducting a systematic literature review. J. Plan. Educ. Res. 2019, 39, 93-112. [CrossRef]

35. Guz, A.N.; Rushchitsky, J.J. Scopus: A system for the evaluation of scientific journals. Int. Appl. Mech. 2009, 45, 351-362. [CrossRef]

36. Chadegani, A.A.; Salehi, H.; Yunus, M.M.; Farhadi, H.; Fooladi, M.; Farhadi, M.; Ale Ebrahim, N. A Comparison between two main academic literature collections: Web of Science and Scopus databases. Asian Soc. Sci. 2013, 9, p18. [CrossRef]

37. Grech, V.; Rizk, D.E.E. Increasing importance of research metrics: Journal Impact Factor and h-index. Int. Urogynecol. J. 2018. [CrossRef]

38. Garrett, R.D.; Carlson, K.M.; Rueda, X.; Noojipady, P. Assessing the potential additionality of certification by the round table on responsible soybeans and the roundtable on sustainable palm oil. Environ. Res. Lett. 2016, 11. [CrossRef]

39. Carlson, K.M.; Heilmayr, R.; Gibbs, H.K.; Noojipady, P.; Burns, D.N.; Morton, D.C.; Walker, N.F.; Paoli, G.D.; Kremen, C. Effect of oil palm sustainability certification on deforestation and fire in Indonesia. Proc. Natl. Acad. Sci. USA 2018, 115, 121-126. [CrossRef]

40. Gatti, R.C.; Liang, J.; Velichevskaya, A.; Zhou, M. Sustainable palm oil may not be so sustainable. Sci. Total. Environ. 2019, 652, 48-51. [CrossRef] [PubMed]

41. Morgans, C.L.; Meijaard, E.; Santika, T.; Law, E.; Budiharta, S.; Ancrenaz, M.; Wilson, K.A. Evaluating the effectiveness of palm oil certification in delivering multiple sustainability objectives. Environ. Res. Lett. 2018, 13. [CrossRef]

42. Kunz, Y.; Otten, F.; Mardiana, R.; Martens, K.; Roedel, I.; Faust, H. Smallholder telecoupling and climate governance in Jambi province, Indonesia. Soc. Sci. 2019, 8, 115. [CrossRef]

43. Furumo, P.R.; Rueda, X.; Rodríguez, J.S.; Ramos, I.K.P. Field evidence for positive certification outcomes on oil palm smallholder management practices in Colombia. J. Clean. Prod. 2019. [CrossRef]

44. Saswattecha, K.; Kroeze, C.; Jawjit, W.; Hein, L. Assessing the environmental impact of palm oil produced in Thailand. J. Clean. Prod. 2015, 100, 150-169. [CrossRef]

45. Brandi, C.; Cabani, T.; Hosang, C.; Schirmbeck, S.; Westermann, L.; Wiese, H. Sustainability standards for palm oil: Challenges for smallholder certification under the RSPO. J. Environ. Dev. 2015, 24, 292-314. [CrossRef]

46. Dermawan, A.; Hospes, O. Sustainability pathways in oil palm cultivation: A comparison of Indonesia, Colombia and Cameroon. In Achieving Sustainable Cultivation of Oil Palm: Introduction, Breeding and Cultivation Techniques; Rival, A., Ed.; Burleigh Dodds Science Publishing: Cambridge, UK, 2018; pp. 33-48.

47. Glasbergen, P. Smallholders do not eat certificates. Ecol. Econ. 2018, 147, 243-252. [CrossRef]

48. Hidayat, N.K.; Glasbergen, P.; Offermans, A. Sustainability certification and palm oil smallholders' livelihood: A comparison between scheme smallholders and independent smallholders in Indonesia. Int. Food Agribus. Manag. Rev. 2015, 18, 25-48.

49. Hidayat, N.K.; Glasbergen, P.; Offermans, A. On the profitability of sustainability certification: An analysis among Indonesian palm oil smallholders. J. Econ. Sustain. Dev. 2016, 7, 45-61. 
50. Hutabarat, S.; Slingerland, M.; Dries, L. Explaining the "certification gap" for different types of oil palm smallholders in Riau Province, Indonesia. J. Environ. Dev. 2019, 28, 253-281. [CrossRef]

51. Shukla, M.; Tiwari, M.K. Big-data analytics framework for incorporating smallholders in sustainable palm oil production. Prod. Plan. Control. 2017, 28, 1365-1377. [CrossRef]

52. Senawi, R. Transformation of oil palm independent smallholders through Malaysian sustainable palm oil. J. Oil Palm Res. 2019, 31, 496-507. [CrossRef]

53. Nurliza, N.; Dolorosa, E.; Suryadi, U.E. Farmers' organizations model of independent smallholders in sustainable palm oil certification. Pertanika J. Soc. Sci. Humanit. 2019, 27, 1843-1863.

54. Schoneveld, G.C.; van der Haar, S.; Ekowati, D.; Andrianto, A.; Komarudin, H.; Okarda, B.; Jelsma, I.; Pacheco, P. Certification, good agricultural practice and smallholder heterogeneity: Differentiated pathways for resolving compliance gaps in the Indonesian oil palm sector. Glob. Environ. Chang. 2019, 57. [CrossRef]

55. Shahida, S.; Bam, H.S.; Hanisah Fuad, S. The effect of sustainability certification for export on operational profitability of Malaysian palm oil companies. J. Ekon. Malays. 2018, 52, 55-67. [CrossRef]

56. Hafizuddin-Syah, B.A.M.M.; Shahida, S.; Fuad, S.H. Sustainability certifications and financial profitability: An analysis on palm oil companies in Malaysia. J. Pengur. 2018, 54, 143-154. [CrossRef]

57. Giessen, L.; Burns, S.; Sahide, M.A.K.; Wibowo, A. From governance to government: The strengthened role of state bureaucracies in forest and agricultural certification. Policy Soc. 2016, 35, 71-89. [CrossRef]

58. Hidayat, N.K.; Offermans, A.; Glasbergen, P. Sustainable palm oil as a public responsibility? On the governance capacity of Indonesian Standard for Sustainable Palm Oil (ISPO). Agric. Hum. Values 2018, 35, 223-242. [CrossRef]

59. Higgins, V.; Richards, C. Framing sustainability: Alternative standards schemes for sustainable palm oil and South-South trade. J. Rural. Stud. 2019, 65, 126-134. [CrossRef]

60. Johnson, A. The roundtable on sustainable palm oil's national interpretation process in Ecuador: 'Fitting' global standards into local contexts. J. Rural. Stud. 2019, 71, 125-133. [CrossRef]

61. Kadarusman, Y.B.; Herabadi, A.G. Improving sustainable development within Indonesian palm oil: The importance of the reward system. Sustain. Dev. 2018, 26, 422-434. [CrossRef]

62. Nesadurai, H.E.S. ASEAN environmental cooperation, transnational private governance, and the haze: Overcoming the 'territorial trap' of state-based governance? TRaNS Trans Reg. Natl. Stud. Southeast Asia 2017, 5, 121-145. [CrossRef]

63. Ponte, S.; Cheyns, E. Voluntary standards, expert knowledge and the governance of sustainability networks. Glob. Networks 2013, 13, 459-477. [CrossRef]

64. Ruysschaert, D.; Carter, C.; Cheyns, E. Territorializing effects of global standards: What is at stake in the case of 'sustainable' palm oil? Geoforum 2019, 104. [CrossRef]

65. Schouten, G.; Hospes, O. Public and private governance in interaction: Changing interpretations of sovereignty in the field of sustainable palm oil. Sustainability 2018, 10, 4811. [CrossRef]

66. Wijaya, A.; Glasbergen, P. Toward a new scenario in agricultural sustainability certification? The response of the Indonesian national government to private certification. J. Environ. Dev. 2016, 25, 219-246. [CrossRef]

67. Winters, P.; Kuo, H.-W.; Niljinda, C.; Chen, B.; Alves-Pinto, H.N.; Ongun, M.; Daryanto, S.; Newton, P. Voluntary certification design choices influence producer participation, stakeholder acceptance, and environmental sustainability in commodity agriculture sectors in tropical forest landscapes. J. Sustain. For. 2015, 34, 581-604. [CrossRef]

68. Martens, K.; Kunz, Y.; Rosyani, I.; Faust, H. Environmental governance meets reality: A micro-scale perspective on sustainability certification schemes for oil palm smallholders in Jambi, Sumatra. Soc. Nat. Resour. 2019, 33, 634-650. [CrossRef]

69. Noor, F.M.; Gassner, A.; Terheggen, A.; Dobie, P. Beyond sustainability criteria and principles in palm oil production: Addressing consumer concerns through in setting. Ecol. Soc. 2017, 22. [CrossRef]

70. United Nations. The Sustainable Development Goals Report 2019. Available online: https://unstats.un.org/sdgs/report/2019 /The-Sustainable-Development-Goals-Report-2019.pdf (accessed on 18 December 2019).

71. ISEAL Alliance. Sustainability Standards and the SDGs: Evidence of ISEAL Members' Contribution. Available online: https: //www.isealalliance.org/get-involved/resources/iseal-report-sustainability-standards-and-sdgs-evidence-iseal-members (accessed on 31 December 2019).

72. Nambiappan, B. Malaysia: 100 years of resilient palm oil economic performance. J. Oil Palm Res. 2018, 13-25. [CrossRef]

73. BERNAMA. BERNAMA.com. Available online: http://bernama.com/en/news.php?id=1769402 (accessed on 31 December 2019).

74. Campbell, K.T. Lost in Translation? An Assessment of the SDGs as a Basis for Private Sector Action: A Case Study of Palm Oil; Institute for Global Prosperity: London, UK, 2019. 